\title{
Clinical and immune effects of fecal microbiota transplantation in children with acute graft-versus-host disease
}

\author{
Oleg V. Goloshchapov ${ }^{1}$, Evgeny A. Bakin ${ }^{1}$, Oksana V. Stanevich ${ }^{1}$, Ruslana V. Klementeva ${ }^{1}$, Alexander A. Shcherbakov ${ }^{1}$, \\ Alexander N. Shvetsov ${ }^{1}$, Olesya V. Paina ${ }^{1}$, Polina V. Kozhokar ${ }^{1}$, Margarita V. Gorchakova ${ }^{1}$, Elena V. Babenko ${ }^{1}$, \\ Maria A. Suvorova ${ }^{2}$, Sergey N. Bondarenko ${ }^{1}$, Maxim A. Kucher ${ }^{1}$, Alexander D. Kulagin ${ }^{1}$, Ludmila S. Zubarovskaya ${ }^{1}$, \\ Ivan S. Moiseev ${ }^{1}$ \\ ${ }^{1}$ Pavlov University, St. Petersburg, Russia \\ ${ }^{2}$ Explana Research Laboratory, St. Petersbug, Russia
}

Oleg V. Goloshchapov, ICU Department, RM Gorbacheva Research Institute of Pediatric Oncology, Hematology and Transplantation, Pavlov University, St. Petersburg, Russia
Phone: +7 (921) 9792913

E-mail: golocht@yandex.ru

Citation: Goloshchapov OV, Bakin EA, Stanevich OV et al. Clinical and immune effects of fecal microbiota transplantation in children with acute graft-versus-host disease. Cell Ther Transplant 2021; 10(1): 69-78.

\section{Summary}

Over last years, an important role of altered gut microbiota and its potential correction was suggested for pediatric cancer and autoimmune disorders. The data from last decade highlight sufficient influence of the main classes of gut bacteria (Firmicutes and Bacteroides) upon development of immune response in oncological disorders and autoagressive conditions, as well as role of their imbalance and its correction using fecal microbiota transplantation (FMT) approach. Our previous studies have shown a pronounced clinical effect of FMT, mostly, in adult patients with severe acute graft-versus-host disease (GVHD). The aim of this article was to present our own experience of FMT in children with intestinal form of GVHD resistant to conventional treatment. Materials and methods. A prospective single-center study included 7 patients aged from 3 to 10 years with severe intestinal GVHD developed after allogeneic hematopoietic stem cell transplantation. Clinical effects of FMT were evaluated by conventional scales during 120 days after the procedure. Time-dependent changes of fecal microbiota were assayed, mainly, by the multiplex polymerase chain reaction (PCR) test-system. Results. We present our own experience of FMT in 7 children with intestinal GVHD and antibiotic-resistant colitis.
Complete or partial response to the GVHD treatment was achieved in 6 cases (86\%) by 120 days, in absence of serious adverse events following FMT. Since day +8 after TFM, increased amounts of B. fragilis gr., Faecalibacterium prausnitzii and $E$. coli were registered in fecal microbiota $(\mathrm{p}<0.048, \mathrm{p}<0.001$, and $\mathrm{p}<0.048$, respectively), in absence of differences for Bifidobacterium spp and Lactobacillus spp.

\section{Conclusion}

Combined therapy with immunosuppressive agents and FMT procedure in the patients with intestinal GVHD resistant to standard therapy is associated with pronounced clinical responses correlating with distinct changes of intestinal microbiota, with acceptable safety profile.

\section{Keywords}

Hematopoietic stem cell transplantation, graft-versushost disease, fecal microbiota transplantation, clinical efficiency. 


\section{Introduction}

Our knowledge on gut microbiota significantly extended over last decades, due to improved cultivation of fastidious bacteria and DNA-based classification. As a result, big classes of anaerobic microbes were revealed, thus allowing renewing phylogenetic tree of gut microflora. Over $80 \%$ of gut bacterial species do not grow on available bacteriological media [1]. Therefore, molecular biology methods (PCR and DNA sequencing) proved to be the most effective methods, both in experimental and clinical studies $[1,2]$. Sequencing of $16 \mathrm{~S}$ rRNA gene became the standard approach to phylogenetic attribution of numerous bacterial types and families inhabiting gut microbiota [3]. Implementation of these echniques allowed us both to assess species composition of gut microbiota (GM), and to revise the role of some bacterial groups in pathogenesis of oncological, infectious and autoimmune diseases. At the present time, two main types of bacteria dominate in human intestines, i.e, Firmicutes and Bacteroidetes [4]. Their ratio and species composition are changing from the first days of life and depends on the mode of birth. Early predomination of Bacteroidetes over Firmicutes is observed in the children born by physiological way. Such altered ratio may influence gut immunity, cause metabolic syndrome, as well as affect maturation of nervous system and immune response [5-9].

Impact of intestinal microbiota upon carcinogenesis and clinical course of malignant diseases is studied to much lesser degree. E.g., well-known antitumor immune surveillance depends on proper maturation of CD4+ T cells as well as cytotoxic NK and NK-T cells $[10,11]$. Gut microbiota is known to be a potent educating factor of adaptive immunity. Hence, it may modulate growth of malignant cells, both in children and adults.

It is known, however, that anticancer therapy of leukemias and solid tumors in children is often associated with severe and durable disruption of intestinal microbiota. These changes are caused by damage of intestinal wall, inhibition of local anti-infectious immunity, usage of systemic broad-spectrum antibiotics. Such negative background results into decrease of the bacterial species with favorable immunological effects, e.g., Bacteroidetes, Ruminococcaceae, Prevotella, Blautia, and expansion of Enterococci, Staphylococci and Gram-negative microbiota which may cause septic complications [12-14].

Recent studies of gut microbiota with deep sequencing technologies have shown that qualitative and quantitative composition of this bacterial community determine the balance between antitumor immune response and immune-mediated complications. This effect is implemented via immune system, lymphocyte subpopulations and cytokine profile. Cancer patients with severe bacterial complications are virtually lacking both anti- as well a proinflammatory populations. Worth of note, neither significant anaerobic group was considered a potentially therapeutic tool. Most of existing bacterial probiotics did not influence prognosis, as shown in oncological patients using sequencing of target bacterial DNA's. Transplantation of fecal microbiota remains the only currently available technique aimed for correction of the required bacterial populations. Of course, FMT is primarily used for treatment of disorders that do not respond to conventional therapies, e.g., resistant pseudomembranous colitis, or intestinal graft-versus-host disease (GVHD) refractory to immunosuppressive treatment.

The aim of current work is to assess effects of gut microbiota transplantation upon the course of severe inflammatory disorder, immune system changes, and gut microbiota correction in cases of life-threatening conditions in pediatric patients.

\section{Patients and methods}

\section{Clinical characteristics and procedures}

Over a period of 2015 to 2020 , seven children ( 4 females and 3 males, 3 to 10 years old) were subjected to FMT. These patients were initially treated for acute lymphoblastic leukemia $(n=4)$, hereditary disorders $(n=3)$, or myelodysplastic syndrome $(n=1)$. The reduced-intensity conditioning regimen included fludarabine with busulfan $(n=3)$, melphalan $(n=3)$, or cyclophosphamide (Cy) $(n=1)$. Hematopoietic stem cell transplantation (HSCT) was performed from haploidentical donors $(n=5)$, or matched related donors $(n=2)$. Posttransplant prophylaxis of acute GVHD was carried out with Cy in 5 patients, combined with tacrolimus $(n=5)$, mycophenolate mofetil $(n=3)$, antilymphocyte globulin was used in three cases. In one patient, GVHD prophylaxis was performed with TCR alpha/beta depletion, rituximab, tocilizumab and abatacept. Despite the preventive therapy, severe intestinal GVHD with intestinal bleeding has been developed in all the described patients. In 2 patients, acute/chronic GVHD (overlap syndrome) was documented. Median term from beginning of acute intestinal GVHD or overlap-syndrome to FMT was 56 (8 to 889) days. Severity grade of acute GVHD was scored as grade IV in four cases, grade 3 in 2 children, and grade II, in one patient. In all the cases, treatment of acute intestinal GVHD was started with steroids at the dose of $2 \mathrm{mg} / \mathrm{kg} /$ day. In cases of failure, the therapy was escalated with ruxolitinib $(0.3 \mathrm{mg} / \mathrm{kg} /$ day $)$, within clinical testing program performed by Russian Ministry of Healthcare (No.2016-29-1). Etanercept was added in 3 patients later in cases of poor effect (25 mg twice a week). Other therapies were applied, i.e., extracorporeal photopheresis $(n=3)$, injections of mesenchymal stem cells $(n=2)$, sirolimus $(n=1)$ or tacrolimus $(\mathrm{n}=1)$.

General state of the patients at FMT was as follows: satisfactory in one case; moderate severity, in 2 patients; and four children were in severe condition. Clinical severity was determined, mainly, by assessment of pain and dyspeptic syndrome pronounced in all the patients. Intestinal bleeding with severe anemia was diagnosed in four patients, bilirubinemia, in 3 cases, pronounced encephalopathy was revealed in 2 children. Due to absence of sufficient clinical effect, FMT was administered, as adopted by the Pavlov University Ethical Board of 30.01.2017, №192). Both examination and treatment was performed under the conditions of Helsinki Declaration. The parents or caretakers signed appropriate informed consent. Inclusion criteria were as follows: acute GVHD grade II-IV, or overlap syndrome with intestinal disorder, steroid-refractory form of GVHD and 
failure of preceding treatment with etanercept or ruxolitinib. Exclusion criteria were not applied, due to severity of the disorder. All the children were in remission of primary disease.

Evaluation of acute intestinal GVHD severity, clinical response in the patients, characteristics of stool, undesirable adverse effects (AE) and pain syndrome was performed according to standard scales [15-19]. Histological examination of colon biopsies was carried out to confirm the intestinal GVHD diagnosis.

The FMT procedure in 5 patients was performed at the intensive care unit. In two cases, FMT was made in the outpatient setting. In four patients (57\%), FT from third-party donors was used, and relatives served as donors in 3 cases (mother, in 1 case, and father, in 2 patients). In all these cases, the FT donors were also donors of hematopoietic stem cells for the same patients. Median age of the donors was 33 (19 to 38 ) years ( 4 females and 3 males). All the donors kept Mediterranean diet.

The routes of fecal transplant administration were as follows: EGD, 2 patients; EGD+ nasointestinal tube, 2 patients. Three children received fecal transplant (FT) per os, in gelatin capsules with frozen fecal microbiota. This route of administration was used for FMT in the patients and control persons [20]. Minimal age of the child treated with capsules was 4 years old.

Upon endoscopic FT administration, fresh native substance was used in two patients, and frozen native material was applied in other 2 cases. The frozen material was stored for a median time of $25(2-104)$ days at $-80^{\circ} \mathrm{C}$. FT was delivered to upper intestine by means of nasointestinal tube, in 3.25 (2-5) séances; to lower intestine, using colonoscopy, 3 times. The gelatin capsules with frozen FT were administered daily 8 ( 5 to 10 ) times, at a dose of 3 to 6 capsules. Single FT dose applied via gastroscopy/nasointestinal tube was 1.7 (0.8-4.8) $\mathrm{ml} / \mathrm{kg}$; by colonoscopy, 9 and $6 \mathrm{ml} / \mathrm{kg}$. Total dose of FT administered by the encapsulation method was 1.1 $(0.6-1.7) \mathrm{g} / \mathrm{kg}$.

Antibacterial prophylaxis was cancelled before FMT period in 3 patients; in one case, the therapy was resumed. Four other patients continued therapy with antibiotics. Due to proven viral gut affection (HHV 6 or EBV virus), four patients received gancyclovir therapy at a dose of $10 \mathrm{mg} / \mathrm{kg}$ daily.

Six patients recovered from GVHD and were followed after FMT at long terms (320-1964 days). Only one patient of the seven died on day +34 with pan-resistant Klebsiella sepsis.

\section{Special laboratory tests}

All the patients underwent clinical and laboratory examinations at the following terms: before FMT, on days $+3,+16$, $+30,+60$, and +120 after the procedure. The last day of FTM was considered Day 0.

Study protocols for FT donors, preparation of frozen encapsulated microbiota, native and frozen material, procedures for injection by intestinal catheters, storage and transportation of capsules with FT were described elsewhere in details [21].
Time dynamics of fecal microbiota before and after FMT was assessed by gene-specific PCR detection of DNA samples extracted from fecal samples using commercial Colonoflor test kit (Explana, St. Petersburg, Russia). This test system allowed quantitative detection of common gut bacteria, as based on multiplex real-time PCR (up to 20 specific bacterial genes and total molecular mass are targeted), being recalculated for $\mathrm{CFU}$ numbers as proposed by the manufacturer.

Immunophenotyping of lymphocyte subpopulations was performed by flow cytometry (Cytomics FC500, Beckman Coulter, USA), with CXP Analysis software (Beckman Coulter) using fluorochrome-labeled antibodies (CD45 FITC/ CD4 PE/CD8 ECD/CD3 PC5, CD19PC7, CD3 FITC/ $\mathrm{CD}(16+56) \mathrm{PE}, \mathrm{CD} 45$ PC5, CD5 FITC/CD23 PE/CD19 ECD, CD27 PC7, Beckman Coulter, USA), Versalyse protocol (Beckman Coulter, USA).

The patients were observed for a median of 585 (34-1948) days after FMT. Clinical response was evaluated according to common scales, assessing intestinal GVHD severity, and Bristol scale of stool quality.

\section{Statistical evaluation}

Due to small sample size, only methods of descriptive non-parametric statistics were used with Statistica software, to evaluate levels of significance for the differences between pre- and post-FMT indices.

\section{Results}

\section{Clinical effects of FMT using clinical response scales}

According to the results of clinical assessment by the mentioned scales, complete or partial response (resp., CR and $\mathrm{PR})$ to the intestinal GVHD therapy was achieved in 6 patients out of 7 by the D+120 post-FMT, with a median time for CR and PR, of, respectively, 9 (2-45) and 34 (4-50) days.

Upon evaluation of the patients' stool by the Bristol scale, partial response ( $>4$ points) was achieved in 6 patients $(86 \%)$ after 120 days, complete response ( $<4$ points) was registered in 5 cases (71\%). Median time for PR and CR following FMT comprised 23 (8-45) and 50 (10-90) days, respectively.

The patients reported positive dynamics after FMT, i.e., reduction of gut-related GVHD symptoms (stool volume, blood admixtures, abdominal pain), mitigated dyspeptic syndrome (vomiting, nausea, anorexia), as shown in Table 1.

\section{Composition and changes of fecal microbiota in FMT donors and recipients}

According to the results obtained by multiplex PCR (Colonoflor system), total intestinal bacterial mass (TBM) in the FMT donors was as follows: $3 \times 10^{12}\left(9 \times 10^{11}-8 \times 10^{12}\right) \mathrm{CFU} / \mathrm{g}$, Lactobacillus spp., $3 \times 10^{6}\left(1 \times 10^{6}-2 \times 10^{8}\right) \mathrm{CFU} / \mathrm{g}$; Bifidobacterium spp, $2 \times 10^{9}\left(9 \times 10^{7}-3 \times 10^{9}\right) \mathrm{CFU} / \mathrm{g}$; E.coli, $3 \times 10^{8}\left(1 \times 10^{6}\right.$ $\left.3 \times 10^{9}\right) \quad \mathrm{CFU} / \mathrm{g}$; B.fragilis group, $2 \times 10^{12}\left(2 \times 10^{10}-5 \times 10^{12}\right)$ CFU/g; F.prausnitzii, $1 \times 10^{10}\left(4 \times 10^{8}-2 \times 10^{11}\right) \mathrm{CFU} / \mathrm{g}$. 
Table 1. Time course of intestinal symptoms at different terms after fecal microbiota transplantation in children with acute GVHD (7 cases)

\begin{tabular}{|c|c|c|c|c|c|c|c|}
\hline \multirow{2}{*}{ Clinical parameters } & \multicolumn{7}{|c|}{ Terms, days after FMT } \\
\hline & Before FMT & $\mathrm{D}+3$ & $D+8$ & $D+16$ & $\mathrm{D}+30$ & $D+60$ & $\mathrm{D}+120$ \\
\hline Stool volume, $\mathrm{ml} / \mathrm{kg} / \mathrm{d}$ & $37.7(23.9-87.9)$ & $34.9(19.2-113.5)$ & $28(5-95.6)$ & $20.2(2.4-92.8)$ & $17.1(2.8-53.1)$ & $5.7(2-8.1)$ & $4.4(2-5.7)$ \\
\hline Stool frequency/d & $10(4.6-19)$ & $10.6(2.7-22.0)$ & $6(2.2-21)$ & $9(2.4-21)$ & $5(3-15.4)$ & $2.5(2-4)$ & $2(1-3)$ \\
\hline $\begin{array}{l}\text { Stool consistency } \\
\text { (Bristol scale) }\end{array}$ & $6(5-7)$ & $6(5-7)$ & $5(5-7)$ & $5(4-6)$ & $5(4-6)$ & $4(4-5)$ & $4(4-5)$ \\
\hline $\begin{array}{l}\text { Intestinal bleeding } \\
\text { (CTCAE score, } 1 \text { to 5) }\end{array}$ & $3(0-4)$ & $1(0-4)$ & $0(0-2)$ & $0(0-1)$ & $0(0-1)$ & 0 & 0 \\
\hline Vomiting frequency/d & $3(0-10)$ & $0.1(0-5)$ & $0(0-6)$ & $0(0-1)$ & $0(0-1)$ & $0(0-1)$ & 0 \\
\hline $\begin{array}{l}\text { Nausea } \\
\text { (CTCAE score, } 1 \text { to 3) }\end{array}$ & $2(1-3)$ & $2(1-3)$ & $1(1-3)$ & $1(0-3)$ & $1(0-1)$ & $1(0-1)$ & $1(0-1)$ \\
\hline Anorexia (CTCAE 1 to 5) & $4(2-4)$ & $3(1-4)$ & $3(1-4)$ & $3(1-4)$ & $3(0-4)$ & $1(0-2)$ & $1(0-2)$ \\
\hline $\begin{array}{l}\text { Abdominal pains } \\
\text { (vis.-analogue scale) }\end{array}$ & $7(0-10)$ & $8(0-10)$ & $1(0-10)$ & $3(0-10)$ & $0(0-10)$ & 0 & 0 \\
\hline
\end{tabular}

Note: The data are presented as median values, with minimal and maximal scores in parentheses.

In the patients, when comparing median values for microbial contents post-FMT, some sufficient dynamics was revealed against initial values (Fig.1). E.g., a significant increase of total bacterial mass was registered on $\mathrm{D}+120(\mathrm{p}<0.02)$. Since $\mathrm{D}+3$, increased values against initial levels were found for B.fragilis group, F.prausnitzii and E.coli (respectively, $\mathrm{p}<0.048$, $\mathrm{p}<0.001$ and $\mathrm{p}<0.048$ ), as seen from Fig. 1 .

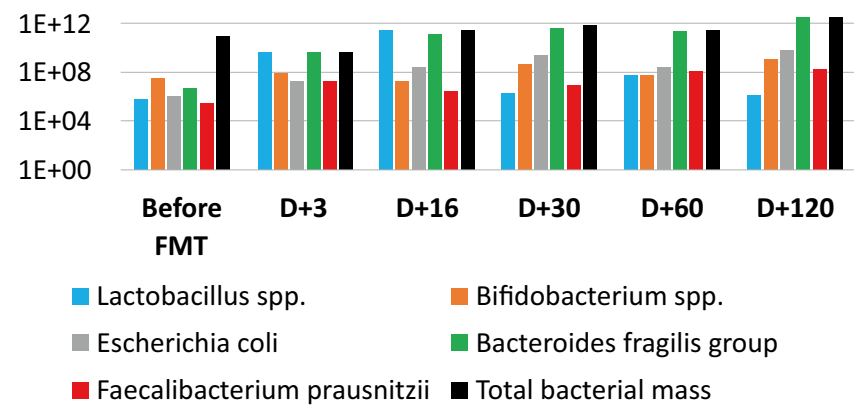

Figure 1. Time-dependent changes of the gut microbiota in pediatric patients $(n=7)$ before and at different terms after fecal microbiota transplantation. Colored bars show median amounts of specific bacterial species and total bacterial mass (TBM).

Abscissa, days posttransplant. Ordinate, $\log _{10}$ of CFU numbers.

E.coli strains found in donor microbiota were tested by Colonoflor system (multiple PCR panel) and no enteropathogenic E.coli genes were revealed.

By the day +120 , no significant differences were noted for Bifidobacterium spp and Lactobacillus spp, compared with their initial levels.

Individual changes of gut bacteria amounts are shown in Fig. 2. In cases of early death $(n=1)$ and of the malignancy relapse $(n=1)$, a decrease of $B$.fragilis and, to lesser degree, Faecalibacterium prausnitzii was noted by the end of observation periods (resp., on $\mathrm{D}+15$ and $\mathrm{D}+120$ ). Hence, recovery of B.fragilis may be an informative marker of gut microbiota recovery which should be tested in more representative groups of patients.

\section{Immunological effects of FMT}

Upon increase in major commensal microorganisms (Bacteroides fragilis, Faecalibacterium prausnitzii) shown by multiple PCR following FMT in patients with acute intestinal GVHD, the number of major lymphocyte subpopulations among surviving children was stable, or became substantially increased for NK cells $(\mathrm{p}<0.05)$, as seen from Table 2 . On the contrary, in a patient with relapse of primary malignan$\mathrm{cy}$, and in the patient who died due to subsequent sepsis, the absolute numbers of major lymphocyte subpopulations were either decreased, or remained at subnormal levels with time, compared to the surviving patients (data not shown).

\section{Adverse effects of FMT}

In 6 patients (86\%), we have observed undesirable events, probably connected with FMT procedure. All these symptoms manifested within 7 days after FMT. However, these side effects were not referred to serious events. Nausea, abdominal pains and stomach rumbling were the most common events (43\%) followed by subfebrile rise of body temperature (29\%). In a single case, vomiting, pronounced abdominal flatulence and intestinal paresis were documented. One patient died on D+34 after FMT with K.pneumonia sepsis diagnosed on $\mathrm{D}+5$, accomplished by fast progression of intestinal GVHD. The patient was previously colonized with pan-resistant K.pneumoniae strain, thus excluding potential negative consequence of FMT procedure. 
Outcome - Death - Recovery - Relapse

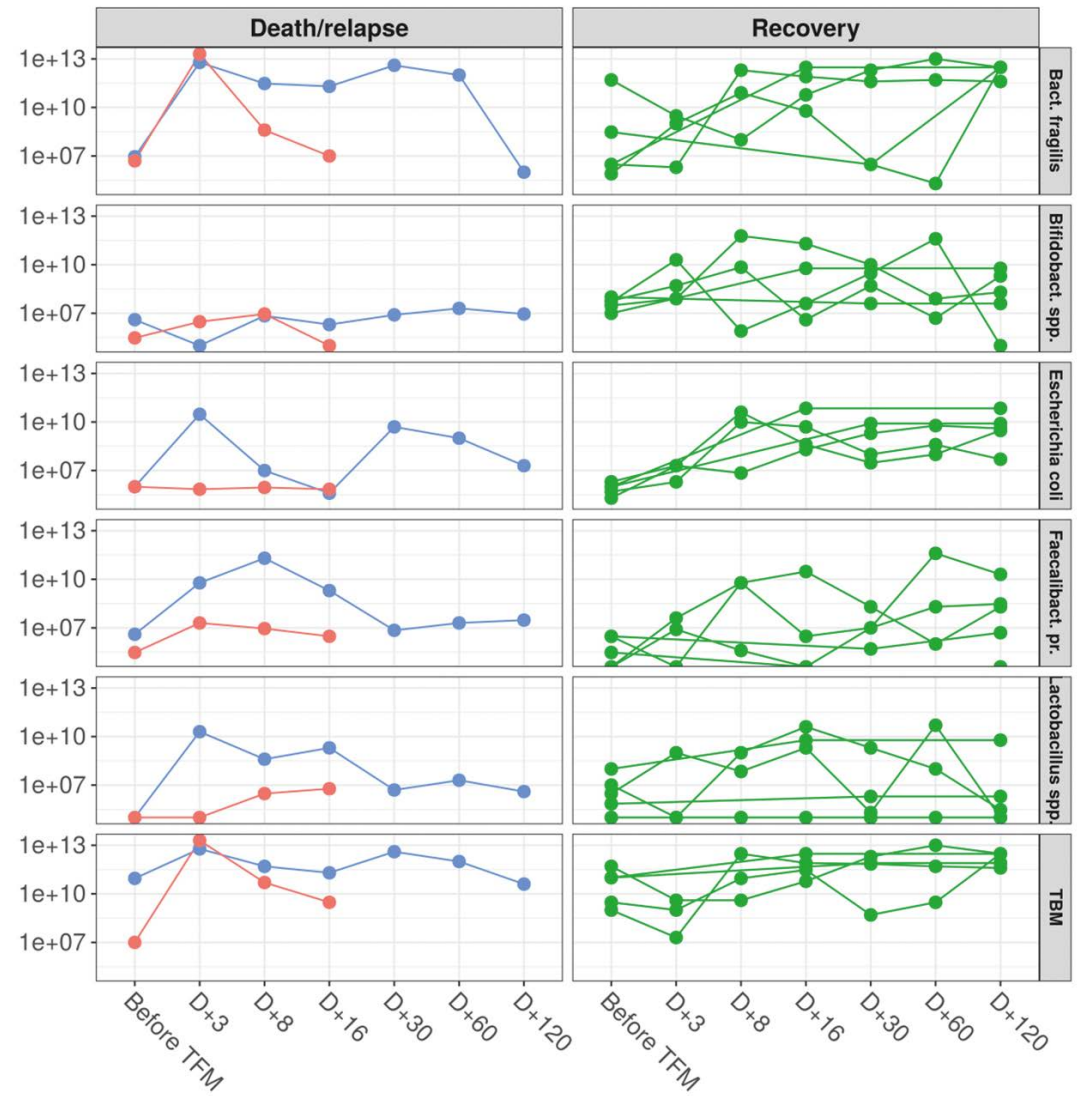

Figure 2. Time-dependent changes of the gut microbiota species and total bacterial mass in pediatric patients before and after fecal microbiota transplantation (FMT). Time dynamics of dead, recovered and recurred (relapsed) patients is marked, respectively, in red, green and blue

Abscissa, terms after FMT, days. Ordinate, bacterial amounts per $g$ of stool derived from multiplex PCR results, recalculated for CFU contents per sample.

Table 2. Time-dependent changes of main lymphocyte populations in peripheral blood of five patients with acute GVHD following fecal microbiota transplantation

\begin{tabular}{|c|c|c|c|c|c|c|c|c|}
\hline Population markers & Relative values & Before FMT & $D+3$ & $\mathrm{D}+8$ & $D+16$ & $\mathrm{D}+30$ & $D+60$ & $D+120$ \\
\hline \multirow{3}{*}{ CD23+ (activated B cells) } & median & $6 e-04$ & 0 & $9 e-04$ & 0.0016 & 0.0012 & 0.044 & 0.0666 \\
\hline & $\min$ & 0 & 0 & 0 & 0 & 0 & 0.001 & 0 \\
\hline & $\max$ & 0.2009 & 0.2442 & 0.2788 & 0.252 & 0.2014 & 0.2622 & 0.1456 \\
\hline \multirow{3}{*}{$\begin{array}{l}\text { CD3-CD(16+56)+ (Natural killer } \\
\text { cells) }\end{array}$} & median & 0.0264 & 0.1815 & 0.1476 & 0.1624 & 0.1596 & 0.1715 & 0.1881 \\
\hline & $\min$ & 0.0205 & 0.0192 & 0.1194 & 0.1204 & 0.1446 & 0.119 & 0.1518 \\
\hline & $\max$ & 0.0562 & 0.1947 & 0.2763 & 0.2925 & 0.165 & 0.1976 & 0.6552 \\
\hline \multirow{3}{*}{ CD3-CD19+ (B lymphocytes) } & median & $9 e-04$ & 0.0016 & 0.0099 & 0.0096 & 0.0012 & 0.111 & 0.3894 \\
\hline & $\min$ & 0 & 0 & 0 & 0 & 0 & 0.002 & 0.1536 \\
\hline & $\max$ & 0.5617 & 0.4026 & 0.6396 & 0.6165 & 0.627 & 0.494 & 0.7696 \\
\hline \multirow{3}{*}{ CD3+CD(16+56)+ (T killer cells) } & median & 0.0048 & 0.0099 & 0.0205 & 0.027 & 0.0153 & 0.017 & 0.0264 \\
\hline & $\min$ & 0.0027 & 0 & 0.0148 & 0.0074 & 0.0152 & 0.0076 & 0.0198 \\
\hline & $\max$ & 0.041 & 0.0099 & 0.0459 & 0.0384 & 0.027 & 0.033 & 0.0884 \\
\hline \multirow{3}{*}{ CD3+CD19- (Total T cells) } & median & 0.2676 & 0.0951 & 0.6093 & 0.5728 & 0.4134 & 0.599 & 2.6367 \\
\hline & $\min$ & 0.0389 & 0.0702 & 0.0772 & 0.0808 & 0.1332 & 0.195 & 0.2442 \\
\hline & $\max$ & 3.4235 & 2.6103 & 3.239 & 3.483 & 2.8614 & 2.9374 & 3.5568 \\
\hline \multirow{3}{*}{ CD3+CD4+ (Helper T cells) } & median & 0.111 & 0.0537 & 0.306 & 0.236 & 0.1758 & 0.433 & 1.378 \\
\hline & $\min$ & 0.0218 & 0.0376 & 0.0388 & 0.044 & 0.0957 & 0.1525 & 0.138 \\
\hline & $\max$ & 2.3821 & 1.8843 & 2.419 & 2.511 & 1.9608 & 2.0634 & 1.8084 \\
\hline \multirow{3}{*}{ CD3+CD8+ (Cytotoxic T cells) } & median & 0.1497 & 0.0399 & 0.2421 & 0.2848 & 0.198 & 0.192 & 0.693 \\
\hline & $\min$ & 0.0031 & 0.0306 & 0.0476 & 0.0488 & 0.0081 & 0.009 & 0.0654 \\
\hline & $\max$ & 0.9594 & 0.6435 & 0.7175 & 0.855 & 0.6992 & 0.6574 & 2.0384 \\
\hline
\end{tabular}

Note: increased ratio of NK cells is shown in bold. 


\section{Discussion}

FMT is presently introduced as experimental therapeutic option for treatment of clinical syndromes with pronounced gut dysbiosis. E.g., incidence of C.difficile infection (CDI) in children and adults is sufficiently increased since 2000 [22-24]. Recurrent CDI develop in ca. $15-30 \%$ of pediatric patients with this infection $[25,26]$. C.difficile-associated syndrome may cause different clinical pattern: from gut colonization to severe fulminant colitis. Many effective antibiotics and immunological therapies are adopted for C.difficile management in adults. However, therapeutic options for children are currently limited [27]. A recent large multicenter study of more than 300 patients aged from 11 to 23 years with C.difficile-associated infection has shown that FMT was clinically successful in $81 \%$ and $90 \%$ of the cases after $1^{\text {st }}$ and $2^{\text {nd }}$ FMT, respectively [28]. FMT becomes a part of therapeutic protocols in pediatrics, when treating recurrent C.difficile infection, being introduced into appropriate guidelines for pediatric patients [29].

There are also some studies of FMT in children with ulcerative colitis [30]. FMT was performed in 21 patients at a mean age of 12 years, in whom clinical response was observed in $57 \%$ and $28 \%$, respectively, at 1 and 6 months after the procedure [31].

Of interest, the prospective study of FMT effects in 20 patients colonized with multiple drug-resistant (MDR) bacteria. Full decolonization of MDR microorganisms was registered in 15 patients [32]. In other study, decolonization of carbapenemase-producing and vancomycin-resistant bacteria was achieved following FMT in 7 of 10 patients [33]. To our knowledge, usage of FMT for decolonization of pan-resistant Gram-negative microbes was not yet reported in pediatric practice. However, FMT in childhood is used rather rarely, due to potential hazards and non-validated treatment techniques. First pediatric FMT was performed 10 years ago in a child 2 years old with recurrent Clostridium difficile infection resistant to standard therapy [34].

Acute GVHD after HSCT, with mortality rates up to $90 \%$, is another complication treated by FMT [35]. Gut dysbiosis in children with acute GVHD was recently demonstrated, with sufficient decrease in anaerobic Firmicutes associated with "anti-inflammatory" effects (Clostridiaceae, Erysipelotrichaceae, Eubacteriaceae, Lachnospiraceae and Ruminococcaceae), compared to GVHD-free patients [36].

Interestingly, the children free of intestinal GHVD exhibited high intestinal levels of obligate anaerobes (Ruminococcaceae) accompanied by fast NK- and B cell reconstitution, and decreased mortality. Vice versa, severe GVHD was related to higher contents of Lactobacillaceae in gut microbiota [37].

The ratio of Enterococcus in adult patients without acute intestinal GVHD was $21 \%$ compared to $46 \%$ incidence in those who subsequently developed this complication, being increased to $74 \%$ in presence of active intestinal GVHD [38]. Meanwhile, Enterococcus spp. was shown to affect epithelial barrier and promote TNF production by the macrophages [39].
Potential efficiency of FMT in acute intestinal GVHD was initially shown in [40]. Complete remission of steroid-resistant intestinal GVHD was reported in 3 of 4 patients following FMT, thus considering this option a quite promising approach for this indication. Current data on FMT usage in acute intestinal GVHD in pediatric patients are quite limited [41].

While being an experimental therapeutic option, pediatric FMT may be applied only at large medical centers, due to lacking treatment standards and absence of appropriate clinical and laboratory staff. However, distinct clinical situations may require urgent FMT intervention, e.g., recurrent fulminant colitis associated with C.difficile infection, or acute severe intestinal GVHD refractory to any immunosuppressive therapy, thus presuming optional off-label FMT procedure. To perform the off-label FMT treatment, this approach meets the following criteria: (1) Severe disorder which is life-threatening, or causing a long-term impaired quality of life; (2) Absence of specific treatment methods; (3) Analysis of research data allows to suggest that the given preparation may achieve clinical effect in the given patients. Moreover, FDA (USA) interprets FMT usage in the following way: if the state of patient without any treatment may move from less severe to more serious, and if a potentially better therapy is available, compared to existing treatment methods. Indications for FMT procedure in acute intestinal GVHD seem to be consistent with these requirements [42].

Safety issues are of most importance in pediatrics, especially, for immunocompromised children following allogeneic HSCT. A sufficient retrospective safety study was performed in 49 children who received 114 FMT procedures [43]. Incidence of short-term undesirable events (UDE) within 48 hours was $26 \%(30 / 114)$. Two severe UDE were observed, and one patient was lost due to bloodstream infection and hepatic failure at $4^{\text {th }}$ week following FMT, with total mortality of $2.04 \%$. Notably, immune state was an independent factor which sufficiently influenced clinical outcomes $(\mathrm{p}=0.002)$. Risk quotient in the patients with immune deficiency proved to be 3.1 . Hence, we must be cautious when performing FMT in children with immune deficiencies.

In the present study, we observed potentially FMT-related adverse effects in $86 \%$ of the cases. However, the undesirable events were not classified as serious, requiring only symptomatic therapy. Longitudinal changes in gut microbiota, metabolome and immune system were not assessed. The observation terms after our $1^{\text {st }}$ pediatric FMT exceed 5 years, without detectable anomalies in growth and developmental, or behavioral deviations. One should observe other patients from our FMT series to these purposes.

To perform FMT in children with intestinal GVHD, encapsulated form of frozen microbiota was used. The youngest patient who received capsules with fecal microbiota was 4 years old. Some FMT studies with capsule administration suggest lower age limits (over 7 years old) for the patients with C.difficile-associated infection [44]. We guess, however, that the main factor is the patient's ability to take encapsulated preparation, not age. According to a survey among 58 gastroenterologists, administration of oral capsules with microbiota to the patients was preferred by $34 \%$ of clinicians [45]. 
Usage of encapsulated form in FMT allows to avoid more invasive procedures, thus being more safe for the children, decreasing both complication rates and treatment costs. In our study, we, generally, followed the FMT protocol proposed by Shouval et al. [46].

There are still insufficient data for a full objective assessment of FMT efficiency in pediatric patients with acute intestinal GVHD, e.g., due to lack of appropriate comparison group. However, our results provide evidence of complete clinical response in 6 of 7 cases within 34 ( 4 to 50) days after FMT. We guess that, in intestinal GVHD, clinical evaluation by means of validated Bristol scale is quite indicative to assess stool normalization and recovery of intestinal functions. By these criteria, complete response ( $<4$ points, solid faeces) was achieved in 5 children (70\%) with steroid-resistant gut GVHD within 10-90 days (median of 50 days), thus being an impressive result. In our previous study which included a mixed-age group treated by FMT ( 13 adults and 6 children), and 8 control cases ( 4 adults and 4 children), we have obtained similar results, i.e., a distinct trend for a faster clinical response was observed in FMT group [47]. The median terms for development of complete response were 34 (3-90) versus 75 (6-91) days in controls. Complete clinical response (CCR) in the FMT group was documented in majority of cases by the day +60 . Clinical improvement in the patients with intestinal GVHD was accompanied by restoration of intestinal B.fragilis, F.prausnitzii and E.coli contents. In contrast, placebo-treated patients did not exhibit any CCR by the day +30 , and only one patient achieved complete response by the day +60 .

Immunotropic effects of commensal gut bacteria, especially, upon major lymphocyte subpopulations may be of great importance for successful therapy of acute intestinal GVHD and survival of children following HSCT. Different lymphocyte dynamics in surviving and deceased patients is in accordance with current views that microbiota may influence human immunity. In our previous study, distinct changes in immune state were shown after FMT in healthy volunteers [20]. An increase in absolute and relative counts of T-helper cells (CD3+ CD4+ CD19+ CD23+) was found by D+9, along with decline in the numbers of cytotoxic T cells (CD3+ CD8+ ) and NK-cells (CD3-CD16+56+). A reversal to normal values was revealed by the $\mathrm{D}+30$.

Other indications for FMT in hematology malignancy are widely discussed recently. Most effects of FMT are yet poorly explored. However, one may formulate several clinical applications for FMT: decolonization of the microorganisms with multiple drug resistance; treatment of C.difficile-associated infection; therapy of autoimmune colitis developing after treatment with PD-1 inhibitors (Nivolumab), or anti-CD20 antibodies (Rituximab) therapy; gut dysbiosis following massive antibacterial therapy; changing sensitivity of malignancies for targeted drugs.

Ethical aspects should be definitely observed, i.e., FMT perception by the children with acute GVHD and their patients. When treating pediatric patients with ulcerative colitis, the authors report tolerance for FMT, and readiness for continuing the therapy [48]. In our opinion, education of parents about the main purposes, mechanisms of FMT action, and its safety should be of utmost importance.

\section{Conclusion}

FMT might be effective in children with severe intestinal GVHD following HSCT. FMT is a relatively safe and feasible procedure in immunocompromised patients upon careful screening of the third-party donors. However, our study has some limitations, i.e., small number of the group and absence of randomized controls. Therefore, larger prospective studies should be performed to better assess safety of FMT in pediatric patients with severe GVHD. Moreover, additional longitudinal studies are required, especially in pediatric patients, in order to assess potential changes in microbiota, metabolome, and immune system. Effective usage of FMT is a pre-requisite for implementation of novel anaerobic bacterial preparations which seem to be used in future, not only for treatment of antibiotic-resistant infections, but also to prevent tumor progression and autoimmune diseases. High-throughput DNA sequencing may provide additional evidence for application of microbiota-based biotherapy in pediatrics.

\section{Acknowledgement}

The study was partially supported by the AdVita Charity Foundation.

\section{Conflicts of interest}

None reported.

\section{References}

1. Rheims H, Rainey FA, Stackebrandt E. A molecular approach to search for diversity among bacteria in the environment. J Ind Microbiol. 1996; 17: 159-169. doi: 10.1007/ BF01574689.

2. Hugenholtz P, Tyson GW, Webb RI, Wagner AM, Blackall LL. Investigation of candidate division TM7, a recently recognized major lineage of the domain Bacteria with no known pure-culture representatives. Appl Environ Microbiol. 2001; 67(1):411-419. doi: 10.1128/AEM.67.1.411-419.2001.

3. Claesson MJ, Jeffery IB, Conde S, Power SE, O'Connor EM, Cusack S, Harris HM, Coakley M, Lakshminarayanan B, O'Sullivan O, et al. Gut microbiota composition correlates with diet and health in the elderly. Nature. 2012; 488(7410):178-184. doi: 10.1038/nature11319.

4. Tanaka M, Nakayama J. Development of the gut microbiota in infancy and its impact on health in later life. Allergol Int 2017; 66: 515-522. doi: 10.1016/j.alit.2017.07.010.

5. Bäckhed F, Ley RE, Sonnenburg JL, Peterson DA, Gordon JI. Host-bacterial mutualism in the human intestine. Science. 2005;307:1915-20. doi: 10.1126/science.1104816.

6. Bercik P. The microbiota-gut-brain axis: learning from intestinal bacteria? Gut. 2011;60:288-289. doi: 10.1136/ gut.2010.226779. 
7. Cryan JF, O'Mahony SM. The microbiome-gut-brain axis: from bowel to behavior. Neurogastroenterol Motil. 2011;23:187-192. doi: 10.1111/j.1365-2982.2010.01664.x.

8. Sherwin E, Sandhu KV, Dinan TG, Cryan JF. May the force be with you: the light and dark sides of the microbiota-gut-brain axis in neuropsychiatry. CNS Drugs. 2016;30:1019-1041. doi: 10.1007/s40263-016-0370-3.

9. Dinan TG, Cryan JF. Gut instincts: microbiota as a key regulator of brain development, ageing and neurodegeneration. J Physiol. 2017;595:489-503. doi: 10.1113/JP273106.

10. Torow N, Yu K, Hassani K, et al. Active suppression of intestinal CD4(+)TCRa $\beta(+)$ T-lymphocyte maturation during the postnatal period. Nat Commun. 2015; 21(6):7725. doi:10.1038/ncomms8725.

11. Olszak T, An D, Zeissig S, Vera MP, Richter J, Franke A, Glickman JN, Siebert R, Baron RM, Kasper DL, Blumberg RS. Microbial exposure during early life has persistent effects on natural killer T cell function. Science. 2012;336(6080):489493. doi: $10.1126 /$ science. 1219328 .

12. Hakim H, Dallas R, Wolf J, Tang L, Schultz-Cherry S, Darling V, Johnson C, Karlsson EA, Chang TC, Jeha S, Pui $\mathrm{CH}$, Sun Y, Pounds S, Hayden RT, Tuomanen E, Rosch JW. Gut microbiome composition predicts infection risk during chemotherapy in children with acute lymphoblastic leukemia. Clin Infect Dis. 2018 Aug 1;67(4):541-548. doi: 10.1093/cid/ciy153.

13. Taur Y, Jenq RR, Ubeda C, van den Brink M, Pamer EG. Role of intestinal microbiota in transplantation outcomes. Best Pract Res Clin Haematol. 2015;28(2-3):155-161. doi: $\underline{10.1016 / \text { j.beha.2015.10.013 }}$

14. Galloway-Peña JR, Smith DP, Sahasrabhojane P, Ajami NJ, Wadsworth WD, Daver NG, Chemaly RF, Marsh L, Ghantoji SS, Pemmaraju N et al. The role of the gastrointestinal microbiome in infectious complications during induction chemotherapy for acute myeloid leukemia. Cancer. 2016;122(14):2186-2196. doi:10.1002/cncr.30039.

15. Glucksberg H, Storb R, Fefer A, Buckner CD, Neiman PE, Clift RA, Lerner KG, Thomas ED. Clinical manifestations of graft-versus-host disease in human recipients of marrow from HLA-matched sibling donors. Transplantation. 1974;18(4):295-304.

16. Martin PJ, Bachier CR, Klingemann HG, McCarthy PL, Szabolcs P, Uberti JP, Schuster MW, Weisdorf D, Chao NJ, Kebriaei P, Shpall EJ, Macmillan ML, Soiffer RJ. Endpoints for clinical trials testing treatment of acute graft-versus-host disease: a consensus document. Biol Blood Marrow Transplant. 2009; 15(7):777-784. doi: 10.1016/j.bbmt.2009.03.012.

17. Lewis SJ, Heaton KW. Stool form scale as a useful guide to intestinal transit time. Scand J Gastroenterol. 1997;32(9):920924. doi: 10.3109/00365529709011203.

18. Common Terminology Criteria for Adverse Events (CTCAE) Version 5.0. https://ctep.cancer.gov/protocolDevelopment/electronic applications/docs/CTCAE v5 Quick Reference 8.5x11.pdf.
19. WHO Guidelines for the Pharmacological and Radiotherapeutic Management of Cancer Pain in Adults and Adolescents. Geneva: World Health Organization; 2018. https://www.who.int/ncds/management/palliative-care/cancer-pain-guidelines/en/

20. Goloshchapov, OV, Olekhnovich EI, Sidorenko SV, Moiseev IS, Kucher MA, Fedorov DE, Pavlenko AV, Manolov AI, Gostev VV, Veselovsky VA et al. Long-term impact of fecal transplantation in healthy volunteers. BMC Microbiol. 2019; 19(1), 312. doi: 10.1186/s12866-019-1689-y.

21. Goloshchapov OV, Churakina DV, Kucher MA, Klement'eva RV, Sidorenko SV, Gostev VV, Karev VE, Suvorova MA, Shlyk IV, Zubarovskaya LS, Afanasyev BV. Fecal microbiota transplantation in critically ill patients in oncohematological practice. Vestnik Anaesthesiol Reanimatol. 2019; 16(3):63-73 (In Russian). doi: 10.21292/2078-5658-2019-163-63-73.

22. Benson L, Song X, Campos J, Singh N. Changing epidemiology of Clostridium difficile-associated disease in children. Infect Control Hosp Epidemiol 2007; 28:1233-1235. doi: $10.1086 / 520732$.

23. Khanna S, Baddour LM, Huskins WC et al. The epidemiology of Clostridium difficile infection in children: a population-based study. Clin Infect Dis 2013; 56:1401-1406. doi: 10.1093/cid/cit075.

24. Kim J, Smathers SA, Prasad P, Leckerman KH, Coffin S, Zaoutis T. Epidemiological features of Clostridium difficile-associated disease among inpatients at children's hospitals in the United States, 2001-2006. Pediatrics 2008; 122:1266-70. doi: 10.1542/peds.2008-0469.

25. Nicholson MR, Thomsen IP, Slaughter JC, Creech CB, Edwards KM. Novel risk factors for recurrent Clostridium difficult infection in children. J Pediatr Gastroenterol Nutr. 2015; 60(1):18-22. doi: 10.1097/MPG.0000000000000553.

26. Kociolek LK, Palac HL, Patel SJ, Shulman ST, Gerding DN. Risk factors for recurrent Clostridium difficile infection in children: A Nested Case-Control Study. J Pediatr. 2015 Aug; 167(2):384-389. doi: 10.1016/j.jpeds.2015.04.052.

27. McDonald LC, Gerding DN, Johnson S, Bakken JS, Carroll K, Coffin S, Dubberke E, Garey K, Gould C, Kelly C et al. Clinical practice guidelines for Clostridium difficile infection in adults and children: 2017 update by the Infectious Diseases Society of America (IDSA) and Society for Healthcare Epidemiology of America (SHEA). Clin Infect Dis. 2018;66(7):e1-e48. doi:10.1093/cid/cix1085.

28. Nicholson MR, Mitchell PD, Alexander E, Ballal S, Bartlett M, Becker P, Davidovics Z, Docktor M, Dole M, Felix $\mathrm{G}$, et al. Efficacy of fecal microbiota transplantation for Clostridium difficile infection in children. Clin Gastroenterol Hepatol. 2020 Mar;18(3):612-619.e1. doi: 10.1016/j. cgh.2019.04.037.

29. Davidovics ZH, Michail S, Nicholson MR, Kociolek L, Pai N, Hansen R, Schwerd T, Maspons A, Shamir R, Szajewska $\mathrm{H}$ et al. Fecal microbiota transplantation for recurrent Clostridium difficile infection and other conditions in 
children: A joint position paper from the North American Society for Pediatric Gastroenterology, Hepatology, and Nutrition and the European Society for Pediatric Gastroenterology, Hepatology, and Nutrition. J Pediatr Gastroenterol Nutr. 2019;68(1):130-143. doi:10.1097/MPG.0000000000002205.

30. Quagliariello A, Del Chierico F, Reddel S, Russo A, Muda AO, D’Argenio P, Angelino G, Romeo EF, Dall'Oglio L, De Angelis P et al. Fecal Microbiota Transplant in Two Ulcerative Colitis Pediatric Cases: Gut Microbiota and Clinical Course Correlations. Microorganisms. 2020;8(10):1486. doi:10.3390/microorganisms8101486.

31. Goyal A, Yeh A, Bush BR, Firek BA, Siebold LM, Rogers MB, Kufen AD, Morowitz MJ. Safety, Clinical Response, and Microbiome Findings Following Fecal Microbiota Transplant in Children With Inflammatory Bowel Disease. Inflamm Bowel Dis. 2018;24(2):410-421. doi: 10.1093/ibd/ $\underline{\mathrm{izx} 035}$.

32. Bilinski J, Grzesiowski P, Sorensen N, Madry K, Muszynski J, Robak K, Wroblewska M, Dzieciatkowski T, Dulny G, Dwilewicz-Trojaczek J et al. Fecal Microbiota Transplantation in Patients With Blood Disorders Inhibits Gut Colonization With Antibiotic-Resistant Bacteria: Results of a Prospective, Single-Center Study. Clin Infect Dis. 2017;65(3):364-370. doi: $10.1093 / \mathrm{cid} / \mathrm{cix} 252$.

33. Battipaglia G, Malard F, Rubio MT, Ruggeri A, Mamez AC, Brissot E, Giannotti F, Dulery R, Joly AC, Baylatry MT et al. Fecal microbiota transplantation before or after allogeneic hematopoietic transplantation in patients with hematologic malignancies carrying multidrug-resistance bacteria. Haematologica. 2019;104(8):1682-1628. doi: 10.3324/haematol.2018.198549.

34. Russell G, Kaplan J, Ferraro M, Michelow IC. Fecal bacteriotherapy for relapsing Clostridium difficile infection in a child: a proposed treatment protocol. Pediatrics. 2010;126 (1): e239-e242. doi: 10.1542/peds.2009-3363.

35. Steinbach G, Hockenbery DM, Huls G, Furlong T, Myerson D, Loeb KR, Fann JR, Castilla-Llorente C, McDonald GB, Martin PJ. Pilot study of lithium to restore intestinal barrier function in severe graft-versus-host disease. PLoS One. 2017;12(8):e0183284. doi: 10.1371/journal.pone.0183284.

36. Simms-Waldrip TR, Sunkersett G, Coughlin LA, Savani MR, Arana C, Kim J, Kim M, Zhan X, Greenberg DE, Xie Y, Davies SM, Koh AY. Antibiotic-Induced Depletion of Anti-inflammatory Clostridia Is Associated with the Development of Graft-versus-Host Disease in Pediatric Stem Cell Transplantation Patients. Biol Blood Marrow Transplant. 2017; 23(5):820-829. doi: 10.1016/j.bbmt.2017.02.004.

37. Ingham AC, Kielsen K, Cilieborg MS, Lund O, Holmes S, Aarestrup FM, Müller KG, Pamp SJ. Specific gut microbiome members are associated with distinct immune markers in pediatric allogeneic hematopoietic stem cell transplantation. Microbiome. 2019; 7(1):131. doi: 10.1186/s40168-0190745-z.

38. Taur Y. Intestinal microbiome changes and stem cell transplantation: Lessons learned. Virulence 2016;7(8):930938. doi: 10.1080/21505594.2016.1250982.
39. Steck N, Hoffmann M, Sava IG, Kim SC, Hahne H, Tonkonogy SL, Mair K, Krueger D, Pruteanu M, Shanahan F et al Enterococcus faecalis metalloprotease compromises epithelial barrier and contributes to intestinal inflammation. Gastroenterology.2011; 141 (3): 959-971. doi: 10.1053/j.gastro.2011.05.035.

40. Kakihana K, Fujioka Y, Suda W, Najima Y, Kuwata G, Sasajima S, Mimura I, Morita H, Sugiyama D, Nishikawa H, Hattori M, Hino Y, Ikegawa S, Yamamoto K, Toya T, Doki N, Koizumi K, Honda K, Ohashi K. Fecal microbiota transplantation for patients with steroid-resistant acute graft-versushost disease of the gut. Blood. 2016; 128(16):2083-2088. doi: 10.1182/blood-2016-05-717652.

41. Zhong S, Zeng J, Deng Z, Jiang L, Zhang B, Yang K, Wang W, Zhang T. Fecal microbiota transplantation for refractory diarrhea in immunocompromised diseases: a pediatric case report. Ital J Pediatr. 2019;45(1):116. doi:10.1186/s13052019-0708-9.

42. Use of fecal microbiota for transplantation to treat Clostridium difficile. Federal Register 2019; 84 (176): 471911. $\quad$ www.federalregister.gov/documents/2019/09/11/2019-19643.

43. Zhang XY, Wang YZ, Li XL, Hu H, Liu HF, Li D, Xiao YM, Zhang T. Safety of fecal microbiota transplantation in Chinese children: A single-center retrospective study. World J Clin Cases. 2018;6(16):1121-1127. doi: 10.12998/wjcc. v6.i16.1121.

44. Youngster I, Mahabamunuge J, Systrom HK, Sauk J, Khalili H, Levin J, Kaplan JL, Hohmann EL. Oral, frozen fecal microbiota transplant (FMT) capsules for recurrent Clostridium difficile infection. BMC Med. 2016;14(1):134. doi:10.1186/s12916-016-0680-9.

45. McIlroy JR, Nalagatla N, Hansen R, Hart A, Hold GL. Faecal microbiota transplantation as a treatment for inflammatory bowel disease: a national survey of adult and paediatric gastroenterologists in the UK. Frontline Gastroenterol. 2018;9(4):250-255. doi: 10.1136/flgastro-2017-100936.

46. Shouval R, Geva M, Nagler A, Youngster I. Fecal microbiota transplantation for treatment of acute graft-versushost disease. Clin Hematol Internat. 2019; 1(1):28-35. doi: 10.2991/chi.d.190316.002.

47. Goloshchapov OV, Bakin EA, Kucher MA, Stanevich OV, Suvorova MA, Gostev VV, Glotov OS, Eismont YA, Polev DE, Lobenskaya A. Bacteroides fragilis is a potential marker of effective microbiota recolonization in acute graft-versus-host disease treatment. Cell Ther Transplant. 2020; 9(2): 47-59. doi:10.18620/ctt-1866-8836-2020-9-2-47-59.

48. Popov J, Hartung E, Hill L, Chauhan U, Pai N. Pediatric Patient and Parent Perceptions of Fecal Microbiota Transplantation for the Treatment of Ulcerative Colitis. J Pediatr Gastroenterol Nutr. 2020. doi: 10.1097/MPG.0000000000002995. Epub ahead of print. PMID: 33230077. 


\title{
Клинико-иммунологические эффекты трансплантации фекальной микробиоты у детей с острой реакцией трансплантат против хозяина
}

\author{
Олег В. Голощапов ${ }^{1}$, Евгений А. Бакин ${ }^{1}$, Оксана В. Станевич ${ }^{1}$ Руслана В. Клементьева ${ }^{1}$, Александр А. Щербаков ${ }^{1}$, \\ Александр Н. Швецов ${ }^{1}$, Олеся В. Паина ${ }^{1}$, Полина В. Кожокарь ${ }^{1}$, Маргарита В. Горчакова ${ }^{1}$, Елена В. Бабенко ${ }^{1}$, \\ Мария А. Суворова ${ }^{2}$, Сергей Н. Бондаренко ${ }^{1}$, Максим А. Кучер ${ }^{1}$, Александр Д. Кулагин ${ }^{1}$, Людмила С. Зубаровская ${ }^{1}$, \\ Иван С. Моисеев ${ }^{1}$ \\ ${ }^{1}$ Первый Санкт-Петербургский государственный медицинский университет им. акад. И. П. Павлова, Санкт-Петербург, \\ Россия \\ ${ }^{2} \mathrm{OOO}$ «Эксплана», Санкт-Петербург, Россия
}

\section{Резюме}

На протяжении последних лет установлена важная роль нарушений кишечной микробиоты и ее потенуиальной коррекции при злокачественных новообразованиях и аутоиммунных заболеваниях у детей. Данные последнего десятилетия выявили существенное влияние основных классов кишечных бактерий (Firmicutes и Bacteroides) на развитие иммунного ответа при онкологических заболеваниях и аутоагрессивных состояниях, а также роль их дисбаланса и коррекции посредством трансплантации фекальной микробиоты (ТФМ). Наши предыдущие исследования показали выраженный клинический эффект ТФМ, в основном, у взрослых пациентов с тяжелой острой реакцией «трансплантат против хозяина» (РТПХ). Целью настоящей работы было представить наш опыт ТФМ у детей с кишечной формой острой РТПХ, резистентной к обычному лечению.

\section{Материалы и методы}

Проспективное одноцентровое исследование включало 7 пациентов в возрасте от 3 до 10 лет с тяжелой кишечной РТПХ после аллогенной трансплантации гемопоэтических стволовых клеток. Клинические эффекты ТФМ определяли с применением стандартных шкал на протяжении 120 сут. после данной процедуры. Временную динамику состава фекальной микробиоты оценивали, главным образом, посредством мультиплексной ПЦР тест-системы.

\section{Результаты}

Мы представили собственный опыт ТФМ у 7 детей с кишечной формой острой РТПХ и антибиотикорезистентным колитом. Полный или частичный ответ на этот вид лечения РТПХ был достигнут в 6 случаях (86\%) в течение 120 сут. в отсутствии серьезных нежелательных эффектов после ТФМ. С 8-го дня после ТФМ было отмечено нарастание содержания B. fragilis gr., Faecalibacterium prausnitzii и E. coli в фекальной микробиоте ( $\mathrm{p}<0,048, \mathrm{p}<0,001$, и $\mathrm{p}<0,048$, соответственно), при отсутствии различий по Bifidobacterium spp. и Lactobacillus spp.

\section{Выводы}

Комбинированная терапия иммуносупрессивными препаратами и ФМТ у пациентов с кишечной формой РТПХ, резистентной к стандартной терапии, сопровождается выраженным клиническим ответом, коррелирующим с определенными изменениями кишечной микробиоты и приемлемыми показателями безопасности процедуры.

\section{Ключевые слова}

Трансплантации фекальной микробиоты, трансплантация гемопоэтических клеток, реакция «трансплантат против хозяина», фекальная микробиота, трансплантация, клиническая эффективность, побочные эффекты. 